BIOFARM

Jurnal Ilmiah Pertanian

ISSN Print: 0216-5430; ISSN Online: 2301-6442

Vol. 15, No. 2, Oktober 2019

\title{
Pengaruh Empat Minyak Atsiri terhadap Jamur Agens Pengendali Hayati
}

\author{
The Effect Of The Four Essential Oils On Fungal Biological Agents
}

\author{
Wahyu Febriyono ${ }^{1 *}$, Heru Adi Djatmiko ${ }^{2}$ \\ ${ }^{1}$ Program Studi Agribisnis, Universitas Peradaban \\ *Korespondensi Penulis:wahyufebriyono@gmail.com
}

\begin{abstract}
ABSTRAK
Kehilangan hasil akibat OPT diperkirakan mencapai 40 - 55\%, bahkan dapat menyebabkan gagal panen. Penggunaan jamur agens pengendali hayati dan penggunaan minyak atsiri adalah alternatif dalam pengendalian OPT. Penelitian ini dilakukan dengan tujuan untuk 1) mengkaji pengaruh minyak atsiri terhadap jamur agens pengendali hayati, 2) mengetahui konsentrasi minyak cengkeh, serai wangi, temulawak dan nilam yang aman untuk pengendalian, 3) mendapatkan jamur non target tahan aplikasi pestisida nabati berbahan aktif minyak cengkeh, serai wangi, temulawak, dan nilam. Konsentrasi minyak atsiri yang diuji adalah $0,04,0,2,1$, dan $5 \%$. Sebagai pembanding adalah air, pelarut (isopropil alkohol, minyak tanah, dan tween 20), dan fungisida (mankozeb $45 \%$ ). Jamur agens pengendali hayati yang digunakan adalah Trichoderma spp, Verticilium spp, Beauveria bassiana, dan Cordyceps sp. Variabel yang diamati dalam penelitian ini adalah penampakan secara visual (warna, miselium aerial), diameter koloni, berat kering miselium. Hasil penelitian menunjukkan bahwa minyak atsiri bersifat racun terhadap jamur agens pengendali hayati. Konsentrasi yang relatif aman untuk pengendalian adalah konsentrasi 0,04\%. Jamur Trichoderma spp. lebih kompatibel terhadap aplikasi minyak atsiri.
\end{abstract}

Kata Kunci : pengendalian hayati, minyak atsiri, pestisida nabati.

\begin{abstract}
Loss yield as a result of it is estimated to reach $40-55 \%$, even it can cause crop failed. Usage of fungi as a biological control agens and volatile oil is an alternative technique to control the pests. This study aims to (1) test volatile oils effect to biological control fungi, (2) detect safe concentration of clove oil, serai wangi, temulawak, and patchouli oil for control application, (3) get non-target fungus which is resistant to biopesticide application by clove oil, serai wangi, temulawak, and patchouli oil active mattered. Concentration of clove oil tested was $0.04,0.2,1$ and $5 \%$. The comparators were water, solvent (isophrophyl alcohol, kerosene, tween 20) and fungicide (mankozeb 45\%), whereas applied of biological control fungi were Trichoderma spp., Verticillium spp., Beauveria bassiana, and Cordyceps sp. Variable observed in this study were visual appereance (colour, aerial mycelia), colony diameter, and mycelium dry weight. Results of this study indicated that volatile oil was toxic to biological control fungi. The relative safe concentration used to control was $0.04 \%$. Trichoderma spp. be more compatible to volatile oil application.
\end{abstract}

Key words : natural control, essential oil, botanical pesticide

\section{PENDAHULUAN}

Salah satu kebutuhan primer manusia adalah kebutuhan hasil pertanian. Ketersediaan hasil pertanian harus sesuai dengan kebutuhan, untuk itu perlu peningkatan produksi pertanian. Semakin bertambahnya penduduk maka kebutuhan hasil pertanian semakin meningkat, sehingga untuk mencukupi kebutuhan tersebut timbul masalah yang cukup besar.

Proses intensifikasi yang ada sekarang ini memberikan berbagai kendala sosialekonomi dan teknis. Masalah organisme pengganggu tanaman (OPT) yang mengakibatkan penurunan dan ketidakmantapan produksi belum dapat diatasi dengan baik. Kehilangan hasil akibat OPT diperkirakan mencapai $40-55 \%$, bahkan dapat menyebabkan gagal panen. Dilema yang dihadapi para petani saat ini adalah bagaimana cara mengatasi masalah OPT tersebut dengan pestisida sintetis. Di satu pihak dengan penggunaan pestisida sintetis, maka kehilangan hasil akibat OPT dapat ditekan, tetapi menimbulkan dampak terhadap lingkungan.

Beberapa dampak negatif yang mungkin timbul akibat penggunaan pestisida dalam bidang pertanian, yang tidak sesuai dengan aturan antara lain pencemaran air, pencemaran udara, timbulnya spesies hama 
yang resistant, timbulnya spesies hama baru atau ledakan hama, resurgensi, merusak keseimbangan ekosistem dan dampak terhadap kesehatan masyarakat (Adriyani, 2006). Pencegahan dapat dilakukan melalui penggunaan pestisida alami yang tidak meninggalkan residu berbahaya dan ramah lingkungan, penggunaan musuh alami hama (predator, parasitoid, dan patogen), biopestisida, rotasi tanaman dan menanam tanaman kawan (companion plant).

Pestisida alami sudah banyak digunakan oleh petani, minyak atsiri merupakan salah satu bahan yang berpotensi sebagai pestisida alami. Minyak atsiri sebagai pestisida nabati karena menghasilkan senyawa volatil yang menunjukkan aktifitas sebagai antibakteri dan antifungal terhadap patogen tanaman (Kivanc dan Akgul dalam Nasrun dan Nuryani, 2007). Minyak atsiri terdapat dalam jenis berbagai tanaman, misalkan bagian tanaman cengkeh, temulawak, nilam dan serai wangi.

Menurut Grainge dan Ahmed (1987 dalam Manoi, 2009), bagian akar, batang dan daun tanaman nilam dapat membunuh ulat Crocidolomia pavonana F. dan Spodoptera litura $F$. yang merupakan hama penting pada tanaman kubis dan kedelai, sedangkan daun dan pucuk nilam dapat mematikan semut (Dolichoderus bituberculatus) dan kecoa (Hemidactylus americana) di dalam rumah. Selain itu, minyak nilam bersifat menolak beberapa jenis serangga seperti ngengat kain (Thysanura lepismetidae), Sitophilus zeamais (kumbang jagung), dan Carpophilus sp. (kumbang buah kering), Aphid (kutu tanaman), dan nyamuk.

Tanaman cengkeh merupakan salah satu tanaman rempah yang dimanfaatkan terutama dalam industri rokok. Selain itu cengkeh dimanfaatkan dalam industri makanan, obat-obatan. Sejak tahun 1990-an bagian-bagian dari tanaman cengkeh, yaitu daun, bunga dan gagangnya telah dimanfaatkan pula sebagai bahan baku pestisida nabati untuk pengendalian hama dan penyakit tanaman (Balfas, 2008). Serai wangi dapat digunakan sebagai pestisida nabati yaitu untuk insektisida, bakterisida, dan nemetisida. Daun dan tangkainya menghasilkan minyak atsiri yang digunakan untuk mengusir nyamuk dan serangga (Wardani, 2009).

Minyak atsiri temulawak dapat digunakan dalam bidang farmasi dan minuman (Armando, 2009). Selain itu, dilaporkan bahwa ekstrak eter temulawak secara in vitro dapat menghambat pertumbuhan jamur Microsporum gypseum, M. canis, dan Trichophytol violaceum (Oehadian et al., 1985 dalam Purnomowati, 2008). Minyak atsiri Curcuma xanthorrhiza juga menghambat pertumbuhan jamur Candida albicans, sementara kurkuminoid C. xanthorrhiza mempunyai daya hambat yang lemah (Oei, 1986 dalam Purnomowati, 2008). Agens hayati adalah setiap organisme yang meliputi spesies, subspecies, varietas, semua jenis serangga, nematoda, protozoa, jamur, bakteri, virus, mikoplasma dan organisme lainnya dalam semua tahap perkembangannya yang dapat digunakan untuk kepentingan pengendalian hama dan patogen atau organisme pengganggu tanaman, proses produksi, pengolahan hasil pertanian, dan berbagai keperluan lainnya (Menteri Pertanian, 1995 dalam Supriadi, 2006).

Trichoderma spp. adalah jamur yang paling umum dijumpai dalam tanah khususnya tanah organik. Trichoderma spp. dikenal sebagai jamur agens pengendali hayati yang memiliki kisaran inang luas. Patogen yang mampu dikendalikan oleh Trichoderma spp. antara lain : Rizoctonia solani, Fusarium oxysporum, Candida albicans, Armillaria mellea, dan Pythium aphanideretum (Soesanto, 2008).

Verticillium spp. termasuk dalam divisi Amastigomycotina, kelas Deuteromycetes. Jamur dalam kelas ini mempunyai banyak spesies yang mampu menyebabkan penyakit pada serangga hama (Ferron, 1985 dalam Prayogo, 2005). Jamur Verticillium digunakan untuk mengendalikan serangga hama terutama dari ordo Homoptera (Cloyd, 2003 dalam Prayogo, 2005) dan Hemiptera (Charnley 2003, dalam Prayogo, 2005).

Dilaporkan telah diketahui lebih dari 175 jenis serangga hama yang menjadi inang jamur $B$. bassiana. Berdasarkan hasil kajian jamur ini efektif mengendalikan hama walang sangit (Leptocorisa oretorius) dan wereng batang coklet (Nilaparvata lugens) pada tanaman padi serta hama kutu tanaman (Aphis sp.) pada tanaman sayuran (Dinas Pertanian DIY, 2005). B. bassiana juga dapat digunakan untuk mengendalikan ulat serendang Xystrocera festiva (Wahyono, 2007). Selain itu, B. bassiana dapat digunakan untuk mengendalikan penggerek buah kopi (Hypothenemus hampel), dan Crocidolomia pavonana (Trizlia dan Nurdin, 2009). Jamur Cordyceps sp. dapat mengendalikan kepompong ulat api Setothosea asigna pada tanaman kelapa sawit. Jamur entomopatogenik tersebut 
merupakan sarana pengendalian hayati yang efektif, efisien, dan aman terhadap lingkungan. (Prawirosukarto, 2008).

Sejauh ini belum diketahui pengaruh dari minyak atsiri terhadap jamur agens pengendali hayati, konsentrasi yang aman untuk jamur agens pengendali hayati dan jamur agens pengendali hayati yang tahan terhadap aplikasi pestisida alami berbahan aktif minyak atsiri. Maka perlu dilakukan penelitian yang bertujuan untuk mengetahui pengaruh pestisida alami terhadap agens pengendali hayati. untuk:

Penelitian ini dilakukan dengan tujuan

1. Mengkaji pengaruh minyak atsiri terhadap jamur agens pengendali hayati

2. Mengetahui konsentrasi minyak cengkeh, serai wangi, temulawak dan nilam yang aman untuk pengendalian.

3. Mendapatkan jamur agens peengendali hayati yang sesuai dengan aplikasi pestisida nabati berbahan aktif minyak cengkeh, serai wangi, temulawak, dan nilam.

\section{METODE PENELITIAN}

Bahan yang digunakan dalam penelitian ini adalah: minyak serai wangi, cengkeh, temulawak, dan nilam, isolat Trichoderma spp., Verticilium spp., $B$. bassiana, Cordyceps sp., medium PDA, larutan tween 20, larutan IPA (isopropil alkohol), larutan $\mathrm{HCl} 1 \%$. Alat yang digunakan dalam penelitian ini adalah cawan petri, pipet, vortek, tabung reaksi, gelas ukur, oven, water bath, erlenmeyer, kamera, timbangan elektrik, penggaris, dan alat tulis.

Penelitian ini terdiri atas 4 percobaan in vitro. Penelitian ini disusun dengan menggunakan rancangan faktorial dengan rancangan dasar rancangan acak lengkap. Empat jamur pengendali hayati diuji dengan minyak atsiri serai wangi, cengkeh, temulawak dan nilam dengan konsentrasi 0,$04 ; 0,2 ; 1$ dan $5 \%$. Selain itu diuji juga pada air, pelarut (isopropil alkohol, tween 20, minyak tanah) dan fungisida berbahan aktif mankozeb 45\%. Jumlah perlakuan 112 perlakuan, setiap perlakuan diulang 3 kali sehinggan ada 336 unit percobaan. Pelarut dibuat dari minyak tanah, isopropil alkohol, dan larutan tween 20 dengan perbandingan $5: 4,5: 0,5$. Larutan uji yang digunakan adalah minyak atsiri dan pelarut dengan perbandingan $3: 7$. Pembuatan minyak atsiri konsentrasi 0,$04 ; 0,2 ; 1$ dan $5 \%$ sebanyak yang diperlukan dengan perbandingan pelarut dan larutan uji.
Jamur pengendali hayati ditumbuhkan dalam cawan petri dengan media PDA. Variabel yang diamati dalam penelitian ini adalah diameter koloni (diukur menggunakan penggaris), dan berat kering miselium. Berat kering miselium diamati dengan cara media biakan diberi larutan $\mathrm{HCl} 1 \%$ sebanyak $10 \mathrm{ml}$, kemudian dipanaskan dengan water bath, setelah medium mencair, disaring dengan kertas saring, lalu ditiriskan. Selanjutnya kertas saring dipanaskan dalam oven, sampai beratnya konstan. Data yang diperoleh dianalisis dengan uji $\mathrm{F} 5$ dan $1 \%$. Apabila berbeda nyata dilanjutkan dengan DMRT pada taraf kesalahan $5 \%$.

\section{HASIL DAN PEMBAHASAN}

\section{Uji Minyak Cengkeh Terhadap Jamur Agens Pengendali Hayati}

Pemberian minyak cengkeh pada semua konsentrasi perlakuan menghambat pertumbuhan jamur agens pengendali hayati. Koloni jamur agens pengendali hayati yang diberi minyak cengkeh memiliki diameter yang lebih kecil dibandingkan dengan koloni jamur kontrol. Hal ini sesuai dengan pendapat Tombe et al. (1999), yang menyatakan bahwa pemberian produk cengkeh ke dalam tanah menghambat mikroba tanah. Hasil analisis statistik pengaruh pemberian minyak cengkeh terhadap perkembangan jamur agens pengendali hayati disajikan pada Tabel 1.

Pada jamur Trichoderma spp. selisih antara kontrol dengan perlakuan berkisar antara 2,13-7,70 cm dan memiliki selisih berat kering antara 60,26-119,80 mg. Jamur Verticillium $s p$. memiliki selisih diameter koloni antara 3,23-5,57 cm, berat kering miselium jamur Verticillium sp. memiliki selisih antara 27,74-48,37 mg. Diameter koloni jamur $B$. bassiana memiliki selisih antara 0,58-1,12 cm, sedangkan berat kering jamur $B$. bassiana pada perlakuan memiliki berat kering yang lebih tinggi dibandingkan kontrol. Diameter koloni jamur Cordycep sp. memiliki selisih antara $0,95-3,20 \mathrm{~cm}$, berat kering miselium pada jamur Cordycep sp. memiliki selisih antara 6,30-29,17 mg.

Keempat jenis jamur agens pengendali hayati yang diamati memberikan pengaruh yang berbeda terhadap pemberian minyak cengkeh. Jamur agens pengendali hayati yang tumbuh dengan cepat secara berturutturut adalah Trichoderma spp., Verticillium sp., Cordyceps sp., dan B. bassiana. 
Tabel 1. Hasil uji lanjut pengaruh minyak cengkeh dan minyak nilam terhadap pertumbuhan jamur agens pengendali hayati

\begin{tabular}{|c|c|c|c|c|c|}
\hline \multicolumn{3}{|c|}{ Minyak Cengkeh } & \multicolumn{3}{|c|}{ Minyak Nilam } \\
\hline Perlakuan & $\mathrm{DK}(\mathrm{cm})$ & BK (mg) & Perlakuan & $\mathrm{DK}(\mathrm{cm})$ & $\mathrm{BK}(\mathrm{mg})$ \\
\hline K1J1 & 8,70 a & $225,93 \mathrm{a}$ & K1J1 & 8,70 a & $225,93 \mathrm{a}$ \\
\hline K2J1 & $4,25 \mathrm{c}$ & $106,20 \mathrm{fg}$ & $\mathrm{K} 2 \mathrm{~J} 1$ & $4,25 \mathrm{~cd}$ & 106,20 fghi \\
\hline K3J1 & $6,57 \mathrm{~b}$ & 128,20 cdef & K3J1 & $6,57 \mathrm{~b}$ & 128,20 cdefghi \\
\hline $\mathrm{C} 1 \mathrm{~J} 1$ & 1,62 efg & $165,67 \mathrm{bc}$ & N1J1 & 3,52 cdefg & 146,03 bcdefgh \\
\hline $\mathrm{C} 2 \mathrm{~J} 1$ & $1,00 \mathrm{fg}$ & $117,50 \mathrm{defg}$ & $\mathrm{N} 2 \mathrm{~J} 1$ & 3,77 cde & 141,07 cdefghi \\
\hline C3J1 & 1,10 efg & 136,87 bcdef & N3J1 & 3,48 cdefgh & $186,17 \mathrm{abc}$ \\
\hline $\mathrm{C} 4 \mathrm{~J} 1$ & 1,08 efg & $106,13 \mathrm{fg}$ & N4J1 & $4,15 \mathrm{~cd}$ & 117,73 defghi \\
\hline $\mathrm{K} 1 \mathrm{~J} 2$ & $6,37 \mathrm{~b}$ & 149,47 bcde & $\mathrm{K} 1 \mathrm{~J} 2$ & $6,37 \mathrm{~b}$ & 149,47 bcdefg \\
\hline $\mathrm{K} 2 \mathrm{~J} 2$ & $3,13 \mathrm{~d}$ & 121,73 defg & $\mathrm{K} 2 \mathrm{~J} 2$ & 3,13 cdefghij & 121,73 defghi \\
\hline $\mathrm{K} 3 \mathrm{~J} 2$ & $6,97 \mathrm{~b}$ & $173,30 \mathrm{~b}$ & $\mathrm{~K} 3 \mathrm{~J} 2$ & $6,97 \mathrm{~b}$ & $173,30 \mathrm{abcd}$ \\
\hline $\mathrm{C} 1 \mathrm{~J} 2$ & $0,95 \mathrm{fg}$ & $101,10 \mathrm{fg}$ & $\mathrm{N} 1 \mathrm{~J} 2$ & 2,53 efghijkl & 111,83 defghi \\
\hline $\mathrm{C} 2 \mathrm{~J} 2$ & $0,87 \mathrm{~g}$ & 115,90 efg & $\mathrm{N} 2 \mathrm{~J} 2$ & 3,05 cdefghij & 130,37 cdefghi \\
\hline $\mathrm{C} 3 \mathrm{~J} 2$ & $0,80 \mathrm{~g}$ & $103,03 \mathrm{fg}$ & $\mathrm{N} 3 \mathrm{~J} 2$ & $1,85 \mathrm{ijkl}$ & $184,93 \mathrm{abc}$ \\
\hline $\mathrm{C} 4 \mathrm{~J} 2$ & $0,80 \mathrm{~g}$ & $106,57 \mathrm{fg}$ & $\mathrm{N} 4 \mathrm{~J} 2$ & 2,67 defghijk & 97,50 fghi \\
\hline $\mathrm{K} 1 \mathrm{~J} 3$ & 1,92 ef & $83,13 \mathrm{~g}$ & $\mathrm{~K} 1 \mathrm{~J} 3$ & 1,92 hijkl & $83,13 \mathrm{i}$ \\
\hline $\mathrm{K} 2 \mathrm{~J} 3$ & $2,02 \mathrm{e}$ & 120,43 defg & $\mathrm{K} 2 \mathrm{~J} 3$ & 2,02 ghijkl & 120,43 defghi \\
\hline K3J3 & $1,33 \mathrm{efg}$ & 137,07 bcdef & $\mathrm{K} 3 \mathrm{~J} 3$ & $1,33 \mathrm{kl}$ & 137,07 cdefghi \\
\hline $\mathrm{C} 1 \mathrm{~J} 3$ & $0,92 \mathrm{fg}$ & 121,97 defg & $\mathrm{N} 1 \mathrm{~J} 3$ & $1,63 \mathrm{jkl}$ & 88,83 ghi \\
\hline $\mathrm{C} 2 \mathrm{~J} 3$ & $0,93 \mathrm{fg}$ & 136,30 bcdef & $\mathrm{N} 2 \mathrm{~J} 3$ & 1,031 & $203,00 a b$ \\
\hline $\mathrm{C} 3 \mathrm{~J} 3$ & $0,93 \mathrm{fg}$ & 153,27 bcde & N3J3 & $1,13 \mathrm{kl}$ & 137,77 cdefghi \\
\hline $\mathrm{C} 4 \mathrm{~J} 3$ & $0,80 \mathrm{~g}$ & $130,90 \mathrm{cdef}$ & $\mathrm{N} 4 \mathrm{~J} 3$ & 2,12 fghijkl & 170,73 abcde \\
\hline $\mathrm{K} 1 \mathrm{~J} 4$ & $4,00 \mathrm{c}$ & 115,00 efg & $\mathrm{K} 1 \mathrm{~J} 4$ & 4,00 cde & 115,00 defghi \\
\hline K2J4 & $3,05 \mathrm{~d}$ & $108,70 \mathrm{fg}$ & K2J4 & 3,05 cdefghij & 108,70 efghi \\
\hline K3J4 & $4,30 \mathrm{c}$ & $85,83 \mathrm{~g}$ & K3J4 & $4,30 \mathrm{c}$ & $85,83 \mathrm{hi}$ \\
\hline $\mathrm{C} 1 \mathrm{~J} 4$ & $1,52 \mathrm{efg}$ & $132,00 \mathrm{cdef}$ & N1J4 & 3,47 cdefgh & 106,83 fghi \\
\hline $\mathrm{C} 2 \mathrm{~J} 4$ & 1,68 efg & 135,97 bcdef & $\mathrm{N} 2 \mathrm{~J} 4$ & 3,68 cdef & 112,23 defghi \\
\hline $\mathrm{C} 3 \mathrm{~J} 4$ & 1,47 efg & $163,40 \mathrm{bc}$ & N3J4 & 3,28 cdefghi & $172,53 \mathrm{abcd}$ \\
\hline $\mathrm{C} 4 \mathrm{~J} 4$ & $0,80 \mathrm{~g}$ & $155,20 \mathrm{bcd}$ & N4J4 & 3,25 cdefghi & 153,37 bcdef \\
\hline
\end{tabular}

Keterangan : Angka yang diikuti huruf yang sama pada kolom yang sama, menunjukan perbedaan yang tidak nyata pada DMRT 5\%. J1 : Trichoderma spp., J2 : Verticilium sp., J3 : Beauveria bassiana, J4 : Cordyceps sp., C1 : minyak cengkeh konsentasi 0,04\%, C2 : minyak cengkeh konsentrasi 0,2\%, C3 : minyak cengkeh konsentrasi $1 \%$, C4 : minyak cengkeh konsentrasi $5 \%$, N1 : minyak nilam konsentrasi $0,04 \%$, N2 : minyak nilam konsentrasi $0,2 \%$, $\mathrm{N} 3$ : minyak nilam konsentrasi $1 \%$, N4 : minyak nilam konsentrasi $5 \%, \mathrm{~K} 1$ : kontrol air, $\mathrm{K} 2$ : kontrol pelarut (isopropil alkohol, tween 20, minyak tanah), K3 : kontrol fungisida berbahan aktif mankozeb, DK : diameter koloni, BK : berat kering miselium.

Urutan tersebut menunjukkan tingkatan besarnya diameter koloni tiap jamur. Jamur Trichoderma spp. merupakan jamur yang paling tahan terhadap pemberian minyak cengkeh. Hal ini ditunjukkan dari bobot kering miselium dan diameter koloni berturut-turut sebesar 165,67 mg dan 1,617 cm yang lebih besar dibandingkan dengan jamur agens pengendali hayati yang lainnya (Tabel 1). Minyak cengkeh mengandung senyawa bioaktif eugenol yang bersifat menghambat perkembangan jamur. Senyawa eugenol dalam minyak cengkeh termasuk allelokemi yang dapat diproduksi tanaman untuk resitensi terhadap patogen (Rice, 1984 dalam Haryanto dan Hidayat, 1991) 
Menurut Manohara dan Noveriza (1999), kandungan minyak cengkeh adalah eugenol dan eugenol asetat, kedua senyawa tersebut bersifat fungisida. Trichoderma spp. memliki kemampuan berkembang cukup cepat. Jamur ini dapat membentuk koloni berdiameter $9 \mathrm{~cm}$ dalam 5 hari pada suhu $20^{\circ}$ C pada medium OA (Soesanto, 2008). Berbeda dengan jamur $B$. bassiana yang memliki kemampuan berkembang yang rendah. Jamur $B$. bassiana hanya dapat membentuk koloni berdiameter 0,6-2,3 cm dalam jangka waktu 8 hari pada suhu $20^{\circ} \mathrm{C}$ (Domsch et al., 1993).

\section{Uji Minyak Nilam Terhadap Jamur Agens Pengendali Hayati}

Pemberian minyak nilam menunjukkan adanya penghambatan terhadap perkembangan jamur agens pengendali hayati. Diameter koloni jamur agens pengendali hayati pada perlakuan kontrol lebih besar dibandingkan dengan koloni yang diberi minyak nilam. Berat kering miselium jamur agens pengendali hayati juga menunjukkan adanya penghambatan minyak nilam terhadap pertumbuhan jamur. Terhambatnya pertumbuhan jamur ditunjukkan pada perlakuan konsentrasi $5 \%$ minyak nilam. Hal ini sesuai dengan pendapat Grainge dan Ahmed (1987 dalam Manoi, 2009), bagian akar, batang dan daun tanaman nilam dapat digunakan sebagai pestisida nabati.

Jamur Trichoderma spp. tumbuh lebih kecil dibandingkan dengan kontrol. Selisih antara kontrol dengan perlakuan berkisar antara 2,13-5,22 cm dan memiliki selisih berat kering antara 39,76-119,73 mg. Jamur Verticillium $\mathrm{sp}$. memiliki selisih diameter koloni antara 3,23-4,52 cm, berat kering miselium jamur Verticillium sp. memiliki selisih antara 1,91-51,97 mg. Diameter koloni jamur $B$. bassiana memiliki selisih antara $0,28-0,88 \mathrm{~cm}$, sedangkan berat kering jamur $B$. bassiana pada perlakuan memiliki berat kering yang lebih tinggi dibandingkan kontrol. Diameter koloni jamur Cordycep sp. memiliki selisih antara 0,32-0,95 cm, berat kering miselium pada jamur Cordycep sp. memiliki selisih antara 2,77-29,17 mg.

Minyak nilam mengandung eugenol dan beberapa senyawa alkohol. Kedua jenis senyawa ini memiliki pengaruh negatif bagi pertumbuhan jamur. Eugenol dapat mengganggu penyusun dinding sel jamur sehingga dinding selnya rusak, sedangkan senyawa alkohol bersifat antijamur yang dapat membunuh jamur. Jamur Trichoderma spp. merupakan jamur agens pengendali hayati yang paling tahan terhadap minyak nilam dibandingkan ketiga jamur agens pengendali hayati yang lainnya. Hasil analisis statistik pengaruh pemberian minyak nilam terhadap perkembangan jamur agens pengendali hayati disajikan pada Tabel 1.

Ketiga jamur yang lain memiliki nilai adaptasi yang lebih rendah terhadap minyak nilam dibandingkan dengan jamur Trichoderma spp. Selain itu akibat senyawa eugenol dan alkohol, juga karena laju pertumbuhannya yang rendah. Jamur $B$. bassiana hanya mampu tumbuh dengan diameter koloni $0,6-2,3 \mathrm{~cm}$ pada suhu $20^{\circ} \mathrm{C}$, jamur Verticillium sp. tumbuh dengan diameter koloni $2,5 \mathrm{~cm}$ pada suhu yang sama selama 10 hari (Domsch et al., 1993). Oleh karena itu pertumbuhannya lebih sedikit dibandingkan dengan jamur Trichoderma spp.

\section{Uji Minyak Serai wangi Terhadap Jamur Agens Pengendali Hayati}

Pemberian minyak serai wangi menghambat perkembangan jamur agens pengendali hayati. Hal ini ditunjukkan dari kecilnya diameter koloni jamur agens dibandingkan dengan perlakuan kontrol. Peningkatan konsentrasi minyak serai wangi yang diberikan semakin menghambat perkembangan jamur agens pengendali hayati. Penghambatan perkembangan koloni jamur agens juga ditunjukkan dari kecilnya berat kering miselium koloni. Hasil analisis statistik pengaruh pemberian minyak serai wangi terhadap perkembangan jamur agens pengendali hayati disajikan pada Tabel 2 .

Jamur Trichoderma spp. tumbuh lebih kecil dibandingkan dengan kontrol. Selisih antara kontrol dengan perlakuan berkisar antara $2,13-4,45 \mathrm{~cm}$ dan memiliki selisih berat kering antara 57,26-119,73 mg. Jamur Verticillium sp. memiliki selisih diameter koloni antara 3,10-4,55 cm, berat kering miselium jamur Verticillium $\mathrm{sp}$. memiliki selisih antara 17,94-44,64 mg. Diameter koloni jamur $B$. bassiana memiliki selisih antara 0,58-0,93 cm, sedangkan berat kering jamur $B$. bassiana pada perlakuan memiliki berat kering yang lebih tinggi dibandingkan kontrol. Diameter koloni jamur Cordycep sp. memiliki selisih antara 0,02-0,93 cm, berat kering miselium pada jamur Cordycep sp. memiliki selisih antara 4,97-29,17 mg. 
Tabel 2. Hasil uji lanjut pengaruh minyak serai wangi dan minyak temulawak terhadap pertumbuhan jamur agens pengendali hayati

\begin{tabular}{|c|c|c|c|c|c|}
\hline \multicolumn{3}{|c|}{ Minyak Serai wangi } & \multicolumn{3}{|c|}{ Minyak Temulawak } \\
\hline Perlakuan & $\mathrm{DK}(\mathrm{cm})$ & $\mathrm{BK}(\mathrm{mg})$ & Perlakuan & $\mathrm{DK}(\mathrm{cm})$ & $\mathrm{BK}(\mathrm{mg})$ \\
\hline $\mathrm{K} 1 \mathrm{~J} 1$ & $8,70 \mathrm{a}$ & $225,93 \mathrm{a}$ & K1J1 & $8,70 \mathrm{a}$ & $225,93 \mathrm{a}$ \\
\hline $\mathrm{K} 2 \mathrm{~J} 1$ & $4,25 \mathrm{c}$ & 106,20 efgh & $\mathrm{K} 2 \mathrm{~J} 1$ & $4,25 \mathrm{c}$ & 106,20 ghijk \\
\hline $\mathrm{K} 3 \mathrm{~J} 1$ & $6,57 \mathrm{~b}$ & 128,20 defg & $\mathrm{K} 3 \mathrm{~J} 1$ & $6,57 \mathrm{~b}$ & 128,20 defghi \\
\hline S1J1 & $7,37 \mathrm{~b}$ & $168,67 \mathrm{bc}$ & $\mathrm{T} 1 \mathrm{~J} 1$ & $1,18 \mathrm{efg}$ & $167,93 \mathrm{bc}$ \\
\hline S2J1 & $6,55 \mathrm{~b}$ & $129,57 \mathrm{def}$ & $\mathrm{T} 2 \mathrm{~J} 1$ & $1,50 \mathrm{efg}$ & $166,53 \mathrm{bc}$ \\
\hline S3J1 & $6,10 \mathrm{~b}$ & 119,13 defgh & $\mathrm{T} 3 \mathrm{~J} 1$ & $1,10 \mathrm{efg}$ & 133,63 cdefgh \\
\hline S4J1 & $4,48 \mathrm{c}$ & 114,57 defgh & $\mathrm{T} 4 \mathrm{~J} 1$ & $1,02 \mathrm{fg}$ & 135,27 cdefgh \\
\hline $\mathrm{K} 1 \mathrm{~J} 2$ & $6,37 \mathrm{~b}$ & $149,47 \mathrm{bcd}$ & $\mathrm{K} 1 \mathrm{~J} 2$ & $6,37 \mathrm{~b}$ & 149,47 bcde \\
\hline $\mathrm{K} 2 \mathrm{~J} 2$ & 3,13 cde & 121,73 defgh & $\mathrm{K} 2 \mathrm{~J} 2$ & $3,13 \mathrm{~d}$ & 121,73 defghij \\
\hline $\mathrm{K} 3 \mathrm{~J} 2$ & $6,97 \mathrm{~b}$ & $173,30 \mathrm{~b}$ & $\mathrm{~K} 3 \mathrm{~J} 2$ & $6,97 \mathrm{~b}$ & $173,30 \mathrm{~b}$ \\
\hline $\mathrm{S} 1 \mathrm{~J} 2$ & 3,27 cde & 104,87 efgh & $\mathrm{T} 1 \mathrm{~J} 2$ & $0,80 \mathrm{~g}$ & 103,03 ghijk \\
\hline $\mathrm{S} 2 \mathrm{~J} 2$ & 2,73 def & 117,13 defgh & $\mathrm{T} 2 \mathrm{~J} 2$ & $0,80 \mathrm{~g}$ & 101,57 ghijk \\
\hline $\mathrm{S} 3 \mathrm{~J} 2$ & 2,65 defg & 104,83 efgh & $\mathrm{T} 3 \mathrm{~J} 2$ & $0,80 \mathrm{~g}$ & 16,701 \\
\hline $\mathrm{S} 4 \mathrm{~J} 2$ & 1,82 efgh & $131,53 \mathrm{cdef}$ & $\mathrm{T} 4 \mathrm{~J} 2$ & $0,80 \mathrm{~g}$ & 105,27 ghijk \\
\hline $\mathrm{K} 1 \mathrm{~J} 3$ & 1,92 efgh & $83,13 \mathrm{~h}$ & $\mathrm{~K} 1 \mathrm{~J} 3$ & $1,92 \mathrm{ef}$ & $83,13 \mathrm{k}$ \\
\hline $\mathrm{K} 2 \mathrm{~J} 3$ & 2,02 efgh & 120,43 defgh & $\mathrm{K} 2 \mathrm{~J} 3$ & $2,02 \mathrm{e}$ & 120,43 efghijk \\
\hline $\mathrm{K} 3 \mathrm{~J} 3$ & $1,33 \mathrm{fgh}$ & 137,07 bcde & $\mathrm{K} 3 \mathrm{~J} 3$ & 1,33 efg & 137,07 bcdefg \\
\hline S1J3 & $1,37 \mathrm{fgh}$ & 94,33 efgh & $\mathrm{T} 1 \mathrm{~J} 3$ & $0,92 \mathrm{~g}$ & 122,23 defghij \\
\hline $\mathrm{S} 2 \mathrm{~J} 3$ & $1,23 \mathrm{gh}$ & 101,43 efgh & $\mathrm{T} 2 \mathrm{~J} 3$ & $0,97 \mathrm{fg}$ & $159,03 \mathrm{bcd}$ \\
\hline S3J3 & $1,02 \mathrm{~h}$ & $92,10 \mathrm{fgh}$ & T3J3 & $0,85 \mathrm{~g}$ & 135,03 cdefgh \\
\hline $\mathrm{S} 4 \mathrm{~J} 3$ & $0,98 \mathrm{~h}$ & $110,50 \mathrm{defgh}$ & $\mathrm{T} 4 \mathrm{~J} 3$ & $1,00 \mathrm{fg}$ & 144,97 bcdef \\
\hline $\mathrm{K} 1 \mathrm{~J} 4$ & $4,00 \mathrm{~cd}$ & 115,00 defgh & $\mathrm{K} 1 \mathrm{~J} 4$ & $4,00 \mathrm{c}$ & 115,00 efghijk \\
\hline $\mathrm{K} 2 \mathrm{~J} 4$ & 3,05 cde & 108,70 defgh & $\mathrm{K} 2 \mathrm{~J} 4$ & $3,05 \mathrm{~d}$ & 108,70 fghijk \\
\hline K3J4 & $4,30 \mathrm{c}$ & $85,83 \mathrm{gh}$ & K3J4 & $4,30 \mathrm{c}$ & $85,83 \mathrm{jk}$ \\
\hline $\mathrm{S} 1 \mathrm{~J} 4$ & $3,98 \mathrm{~cd}$ & 97,83 efgh & $\mathrm{T} 1 \mathrm{~J} 4$ & $0,80 \mathrm{~g}$ & 98,10 hijk \\
\hline S2J4 & $3,62 \mathrm{~cd}$ & 101,43 efgh & $\mathrm{T} 2 \mathrm{~J} 4$ & $0,80 \mathrm{~g}$ & $93,67 \mathrm{ijk}$ \\
\hline S3J4 & $3,07 \mathrm{cde}$ & 105,63 efgh & $\mathrm{T} 3 \mathrm{~J} 4$ & $0,80 \mathrm{~g}$ & 100,23 ghijk \\
\hline S4J4 & $3,50 \mathrm{~cd}$ & 110,03 defgh & $\mathrm{T} 4 \mathrm{~J} 4$ & $0,80 \mathrm{~g}$ & $94,57 \mathrm{ijk}$ \\
\hline
\end{tabular}

Keterangan : Angka yang diikuti huruf yang sama pada kolom yang sama, menunjukan perbedaan yang tidak nyata pada DMRT 5\%. J1: Trichoderma spp., J2 : Verticilium sp., J3 : Beauveria bassiana, J4 : Cordyceps sp., C1: minyak cengkeh konsentasi $0,04 \%, \mathrm{C} 2$ : minyak cengkeh konsentrasi $0,2 \%, \mathrm{C} 3$ : minyak cengkeh konsentrasi $1 \%$, C4 : minyak cengkeh konsentrasi $5 \%, \mathrm{~N} 1$ : minyak nilam konsentrasi 0,04\%, N2 : minyak nilam konsentrasi $0,2 \%$, N3 : minyak nilam konsentrasi 1\%, N4 : minyak nilam konsentrasi 5\%, K1 : kontrol air, K2 : kontrol pelarut (isopropil alkohol, tween 20, minyak tanah), K3 : kontrol fungisida berbahan aktif mankozeb, DK : diameter koloni, BK : berat kering miselium.

Serai wangi (Cymbopogon nardus) dapat dimanfaatkan sebagai pestisida nabati karena mengandung sitronelal dan geraniol yang merupakan komponen utama minyak serai wangi (Guenther 1994, dalam Nasrun dan Nuryani, 2007). Kedua komponen tersebut mempunyai sifat antibakteri dan antifungal yang sangat kuat (Sait 1991, dalam Nasrun dan Nuryani, 2007). Serai wangi mengandung senyawa bioaktif yang dapat menginaktivasi kerja enzim pada tubuh jamur agens. Enzim pada jamur yang tidak aktif akan mengakibatkan terhambatnya metabolisme dalam tubuh dan menghambat aktivitas pertumbuhan jamur. Kondisi seperti ini jika berlangsung lama dapat menyebabkan pertumbuhan jamur terhenti (Kamus IImiah, 2009). 
Jamur Trichoderma spp merupakan jamur yang paling tahan terhada $p$ pemberian minyak serai wangi dibandingkan dengan ketiga jamur agens pengendali hayati yang lainnya. Menurut Soesanto (2008), penggunaan jamur Trichoderma spp. sebagai agens pengendali hayati dapat diberikan bersamaan dengan fungisida.

\section{Uji Minyak Temulawak Terhadap Jamur Agens Pengendali Hayati}

Hasil analisis statistik pengaruh pemberian minyak temulawak terhadap perkembangan jamur agens pengendali hayati disajikan pada Tabel 3. Jamur Trichoderma spp. tumbuh lebih kecil dibandingkan dengan kontrol. Selisih antara kontrol dengan perlakuan berkisar antara 2,13-7,68 cm dan memiliki selisih berat kering antara 58,00$119,73 \mathrm{mg}$. Jamur Verticillium sp. memiliki selisih diameter koloni antara 3,23-5,56 cm, berat kering miselium jamur Verticillium sp. memiliki selisih antara 27,74-132,72 mg. Diameter koloni jamur $B$. bassiana memiliki selisih antara 0,58-1,07 cm, sedangkan berat kering jamur $B$. bassiana pada perlakuan memiliki berat kering yang lebih tinggi dibandingkan kontrol. Diameter koloni jamur Cordycep sp. memiliki selisih antara 0,95-3,2 cm, berat kering miselium pada jamur Cordycep sp. memiliki selisih antara 6,3-29,17 mg.

Pemberian minyak temulawak pada semua konsentrasi perlakuan menghambat perkembangan jamur agens pengendali hayati. Hal ini ditunjukkan dari diameter koloni jamur yang lebih kecil dibandingkan dengan kontrol. Hal ini dikarenakan minyak temulawak mengandung senyawa kurkumin. Kurkumin memiliki sifat asam. Sifat asam ini akan menyebabkan terjadinya denaturasi protein pada dinding sel jamur. Hal ini menyebabkan rusaknya sel jamur dan jamur terhambat perkembangannya (Idris et al., 1997).

Kurkumin sebagai senyawa bioaktif dari minyak temulawak memiliki mekanisme untuk menghambat perkembangan jamur agens pengendali hayati. Senyawa bioaktif ini akan bereaksi dengan membran sitoplasma jamur dan mempengaruhi integritas membran sitoplasma. Integritas membran sitoplasma yang terganggu dapat menyebabkan kebocoran meteri intraseluler (Rahmawati et al, 2014). Kurkumin dapat digunakan sebagai pestisida nabati dan berpengaruh terhadap jamur agens pengendali hayati. Dilaporkan bahwa ekstrak eter temulawak secara in vitro dapat menghambat pertumbuhan jamur
Microsporum gypseum, $M$. canis, dan Trichophytol violaceum (Oehadian et al., 1985 dalam Purnomowati, 2008). Minyak atsiri $C$. xanthorrhiza juga menghambat pertumbuhan jamur Candida albicans, sementara kurkuminoid $C$. xanthorrhiza mempunyai daya hambat yang lemah (Oei, 1986 dalam Purnomowati, 2008).

Perkembangan keempat jamur agens pengendali hayati yang paling dapat beradaptasi terhadap pemberian minyak temulawak adalah jamur Trichoderma spp. Jamur Trichoderma spp. yang memiliki cakupan inang yang cukup luas ini mampu berkembang dilingkungan yang cukup asam. Senyawa kurkumin merupakan senyawa fenol yang dapat menyebabkan suasana asam pada media tumbuh (Domsch et al., 1993).

Faktor lain penghambatan pertumbuhan jamur agens pengendali hayati dalam penelitian ini adalah penggunaan jenis pelarut yang digunakan. Pelarut yang digunakan mengandung minyak tanah, isopropyl alcohol dan tween 20. Isopropil alkohol merupakan senyawa antikuman (Klik Dokter, 2008), minyak tanah digunakan untuk meningkatkan toksisitas minyak atsiri. Tween 20 merupakan zat yang berfungsi sebagai perata agar zat dapat menyatu, tween 20 berbahan aktif sorbitan monolaurat atoksilat (Soesanto, 2008).

\section{SIMPULAN}

Berdasarkan penelitian ini dapat disimpulkan bahwa :

1. Minyak atsiri cengkeh, nilam, serai wangi dan temulawak bersifat racun terhadap jamur agens pengendali hayati.

2. Konsentrasi yang relatif aman untuk pengendalian adalah konsentrasi $0,04 \%$.

3. Jamur Trichoderma spp. lebih sesuai dengan aplikasi minyak atsiri cengkeh, nilam, serai wangi dan temulawak.

\section{DAFTAR PUSTAKA}

Alexopoulos, C.J., C.W. Mims. and M. Blackwell. 1996. Introductory of Mycology 4Th Editions. John Wiley and Sons, Inc. New York. 215-257 p.

Adriyani, R. 2006. Usaha Pengendalian Pencemaran Lingkungan Akibat Penggunaan Pestisida Pertanian. Jurnal Kesehatan Lingkungan 3 (1)

Armando, R. 2009. Memproduksi 15 Minyak atsiri Berkualitas. Penebar Swadaya. Jakarta. 115 hal. 
Balfas, R. 2008. Potensi Minyak Daun Cengkeh Sebagai Pengendali Planococcus minor (mask.) (Pseudococcidae; Homoptera) pada Tanaman Lada. Bul. Littro. Vol. XIX (1) $78-85$

Dinas Pertanian Propinsi DIY. 2005. Manfaat Beauveria bassiana dalam Pengendalian WBC (On-line). http://distan.jogjaprov.go.id/manfaat -beauveria-bassiana-dalampengendalian-wbc/ diakses tanggal 20 September 2019.

Domsch, K.H., W. Goms, and T.H.Anderson. 1993. Compendium of Soil Fungi. IHW. Verlag. Netherlands. 325-328 p.

Klik Dokter. 2008. Pentingnya Kebersihan Tangan, Mikroorganisme vs Antiseptik (On-line). http://www.klikdokter.com/ads1/spo nsor/read/2010/08/16/3/25/mikroorg anisme-vs-antiseptic. diakses tanggal 20 September 2019.

Haryanto, T.A.D. dan P. Hidayat. 1991. Bioassay Ekstrak Akar Tumbuhan Acanthus illicifolius Linn terhadap Pertumbuhan Bakteri Pseudomonas solanacearum E.F.Smith. Laporan Penelitian. Fakultas Pertanian, Universitas Jendral Soedirman. Purwokerto (Tidak dipublikasikan).

Idris, H.A.H., S.E. Sumantri, dan A. Wirdha. 1997. Pengaruh Minyak Cengkeh terhadap Pseudomonas solanacearum di Pembibitan Tembakau. Prosiding Kongres Nasional XIV dan Seminar IImiah. Perhimpunan Fitopatologi Indonesia. Palembang. 477 - 480 hal.

Kartasapoetra, G. 1992. Budidaya Tanaman Berkasiat Obat. P.T. Rineka Cipta. Jakarta. 135 hal.

Mangun, H. M. S. 2005. Nilam. Penebar Swadaya. Jakarta. 84 hal.

Manohara, D. dan R. Noveriza. 1999. Potensi Tanaman Rempah dan Obat Sebagai Pengendali Jamur
Phythopthora capsici. Prosiding Forum Komunikasi IImiah Pemanfaatan Pestisida Nabati. Bogor 9 - 10 Nopember 1999.

Manoi, F. 2009. Perkembangan Teknologi Pengolahan dan Penggunaan Minyak Nilam Serta Pemanfaatan Limbahnya (Online). https://docplayer.info/46232861-

Perkembangan-teknologipengolahan-dan-penggunaanminyak-nilam-serta-pemanfaatanlimbahnya .html diakses tanggal 20 September 2019.

Nasrun dan Nuryani. 2007. Penyakit Layu Bakteri pada Nilam dan Stretegi Pengendaliannya. Balai Penelitian Tanaman Obat dan Aromatik, Bogor (On-line). https://anekaplanta.wordpress.com/ 2009/01/27/penyakit-layu-bakteripada-nilam-dan-strategipengendaliannya/ diakses tanggal 20 September 2019.

Prayogo, Y. dan Suharsono. 2005. Optimalisasi Pengendalian Hama Pengisap Polong Kedelai (Riptortus linearis) dengan Cendawan Entomopatogen Verticillium lecanii. Jurnal Litbang Pertanian 24 (4).

Prawirosukarto S., A Susanto., R Y Purba \& B. Drajat, 2008. Teknologi Pengendalian Hama dan Penyakit pada Kelapa Sawit : Siap Pakai dan Ramah Lingkungan. Pusat Penelitian Kelapa Sawit, Medan. Sumatera Utara.

Rahmawati N., Edhy Sudjarwo dan Eko Widodo. 2014. Uji aktivitas antibakteri ekstrak herbal terhadap bakteri Escherichia coli. Jurnal IImuIImu Peternakan 24 (3): 24 - 31.

Purnomowati, S. 2012. Khasiat Temu Lawak Tinjauan literatur tahun 1980 -1997. https://bingkaimedia.com/web/lokas i-hunting/khasiat-temu-lawak/ (on line) diakses tanggal 20 September 2019.

Soesanto, L. 2008. Pengantar Pengendalian Hayati Penyakit Tanaman. Rajawali Press. Jakarta. 573 hal. 
Supriadi. 2006. Analisis Risiko Agens Hayati Untuk Pengendalian Patogen pada Tanaman (On-line) https://docplayer.info/29701367-

Analisis-risiko-agens-hayati-untukpengendalian-patogen-padatanaman-supriadi.html diakses tanggal 20 September 2019.

Tombe, M., Sukamto, Zulhisnain dan E. Taufiq. 1999. Pengaruh Produk Cengkeh Terhadap Populasi Mikroba Tanah dan Intensitas Serangan Fusarium oxysporum f.sp. vanilae. Prosiding Forum Komunikasi Ilmiah Pemanfaetan Pestisida Nabati. Bogor 9 - 10 Nopember 1999.

Trizelia \& Nurdin F. 2010. Virulence of Entomopathogenic Fungus Beauveria bassiana isolates to Crocidolomia pavonana $\mathrm{F}$ (Lepidoptera: Crambidae) Jurnal Agrivita 32(3): 254-260.
Wahyono, T. E. dan T. Nurbetti. 2007. Uji Patogenisitas Agen Hayati Beauveria bassiana DAN Metarhizium anisopliae Terhadap Ulat Serendang (Xystrocera festiva) (On-line).

http://203.190.37.42/publikasi/bt121 078.pdf diakses tanggal 20 September 2019.

Wardani, S. 2009. Uji Aktivitas Minyak Atsiri Daun dan Batang Serai (Andropogon nardus L) Sebagai Obat Nyamuk Elektrik Terhadap Nyamuk Aedes aegypti. Skripsi. Universitas Muhammadiyah Surakarta 